УДК 656.223

ЗАСТОСУВАННЯ ГЕНЕТИЧНИХ АЛГОРИТМІВ НА СТАДІЇ ПЛАНУВАННЯ ЗМІШАНИХ ПЕРЕВЕЗЕНЬ У МІЖНАРОДНОМУ СПОЛУЧЕННІ

Д-р техн. наук Д. В. Ломотько, магістрант Д. Д. Ковальов

\title{
APPLICATION OF GENETIC ALGORITHMS AT THE PLANNING STAGE OF
} INTERNATIONAL INTERMODAL TRANSPORTATIONS

D. Sc. (Tech.) D. V. Lomotko, master D. D. Kovalov

Анотація. Потреби у переміщенні товарів завжди були ключовою складовою суспільства. Важко уявити сучасну країну без розвинених транспортних систем $i$ технологій, саме тому протягом останніх десятиліть упроваджуються новітні 
комп'ютерні системи для задоволення потреб перевізників. Дослідження иього сегмента логістики показують, що складність технологічного процесу міжнародних зміманих перевезень завдає певних проблем усім учасникам транспортування. Стаття описує використання програмного забезпечення на базі генетичних алгоритмів для врегулювання та покращення використання комериійних умов - Інкотермс 2020. Беручи до уваги усі недоліки існуючих програмних засобів, запропоновано використання евристичного підходу для пошуку оптимального варіанта перевезень та автоматизації процесу планування.

Ключові слова: інтермодальні перевезення, генетичні алгоритми, Інкотермс, оптимальний маршрут, митні прочееури, евристичні методи.

Abstract. The necessity to transport goods has always been a crucial component of every society. It is difficult to imagine a modern country without an advanced transport network and technology, which is why the latest computer systems have been developed over the past decades to meet the needs of carriers. The study of this logistics segment shows that the complexity of the technological process of international intermodal transportation causes a range of problems to all parties involved in transportation. An advanced transport network provides a large number of possible options for the transportation of goods or commodities. That is why the computerization of the planning process is the next step in the evolution of transport logistics. This article describes the usage of software based on genetic algorithms to settle and improve the use of commercial Incoterms 2020. Taking into account all the limitations of existing software, it is proposed to use a heuristic approach to find the optimum transportation option and automate the planning process. Ukraine has always assigned a priority role to the railway mode of transport. This is why the railway industry has always been an integral part of the multimodal transportation process. Analysis of imports and exports shows stable growth over the past ten year period. Additionally, Ukraine enjoys a very advantageous geographical location, in that four important transport corridors cross the territory of our country. Studies indicate that innovations in this area will positively contribute to the credibility of Ukrainian carriers. Further, the article describes the typical problems that arise during the usage of the basic Incoterms terms of delivery, including the complexity of customs procedures and clearance of goods, as well as unforeseen monetary costs arising from the difference in the laws of the countries participating in the transportation process. The author proposes the automation of the transportation planning process as a key to solving these disadvantages. The proposed innovation does not require significant investment and can create positive economic value by substantially reducing the cost of transportation.

Keywords: intermodal transportation, genetic algorithms, Incoterms, optimal route, customs procedures, heuristic methods.

Вступ. Географічне розташування України сприятливо впливає на розвиток торгово-економічних відносин 3 країнами світу. 3 погляду транспортної логістики Україна відводить пріоритетну роль саме залізничному виду транспорту. Саме тому залізнична галузь $\epsilon$ невід' $є$ мною складовою перевізного процесу у змішаному сполученні. Труднощі виникають не лише через велику кількість можливих варіантів одного і того самого перевезення, а й через складність митних процедур. Незважаючи на те що у 1936 році Міжнародна торговельна палата представила перші правила Інкотермс, стадія планування перевезення досі передбачає високу вірогідність помилки, що викликає непередбачені витрати і знижує прибуток учасників транспортування. Дослідження стверджують, що більшість помилок виникає саме через людський фактор або брак достатньої кількості інформації. Отже, автоматизація процесу планування 
виступає наступним кроком у розвитку транспортної логістики.

Проаналізувавши математичні моделі та методи, які використовують сучасні програмні забезпечення, можна дійти висновку, що лідерами $є$ евристичні підходи до вирішення задач оптимізації.

Аналіз останніх досліджень i публікацій. Питання впровадження автоматизованих систем потребує застосування наукового підходу та докладного аналізу існуючих моделей. Існують два типи програм, які виконують оптимізаційну функцію, спираючись на точні та евристичні методи. Обидва застосовувались для вирішення задач оптимізації маршрутів прямування залежно від обраного основного критерію. Наприклад, для пасажирських перевезень закордонні онлайн-сервіси пропонують розрахунок вартості заданого маршруту. Однак існують певні проблеми, які не враховуються у вищезгаданих ресурсах:

- не було запропоновано «онлайнкалькулятора» для інтермодальних вантажних перевезень;

- більшість із сервісів пропонують оптимальний варіант, спираючись лише на один обраний критерій;

- не беруться до уваги юридичні особливості країн експорту або імпорту;

- не пропонуються можливі варіанти застосування термінів Інкотермс;

- достовірність даних.

Усі зазначені недоліки впливають на кінцевий результат i можуть погіршити кінцеві економічні, технічні та технологічні показники транспортування.

Вивченням і впровадженням генетичних алгоритмів займалися такі науковці, як Бутько Т. В., Прохоров В. М., Фейгін В. С., Журавльов С. Ю., Кондратьєва А. В. та ін. Журавльов i Фейгін розглядають використання генетичних алгоритмів для зменшення енерговитрат при застосуванні машинно-тракторних агрегатів [17]. Була запропонована модель на основі генетичних алгоритмів для автоматизації оперативної роботи на сортувальних станціях [12]. Також генетичні алгоритми використову-валися для пошуку оптимального рішення задачі комівояжера [18].

Визначення мети та завдання дослідження. Основна мета дослідження полягає в аналізі комп'ютерних моделей у плануванні інтермодального перевезення при використанні базисних умов поставок Інкотермс. Для досягнення поставленої мети потрібно:

- дослідити схожі існуючі моделі та методи;

- проаналізувати переваги та недоліки правил Інкотермс 2020;

- описати та проаналізувати модель на наочному прикладі.

Основна частина дослідження. Інтермодальне перевезення - послідовне перевезення вантажів двома або декількома видами транспорту в одній і тій самій інтермодальній/комбінованій транспортній одиниці без перевантаження самого вантажу при зміні виду транспорту. Його організатор на всіх етапах розробки i здійснення перевізного процесу цілеспрямовано погоджує дії всіх сторін, що беруть участь у ньому вантажовласників, перевізників i перевізних комплексів - в інтересах прискорення перевезення товарів і зниження сукупних витрат на їхнє перевезення.

На сьогоднішній день існує тенденція до систематизації змішаних перевезень. Усі методи планування поставленого завдання можна умовно поділити на дві групи: точні та евристичні методи. Точні методи гарантовано знаходять, маючи достатньо часу, оптимальний шлях. Евристичні методи знаходять, часто за значно коротший час, гарні розв'язки, що, в загальному випадку, можуть бути гіршими за оптимальні. Розвинена транспортна система передбачає велику кількість можливих варіантів одного i того самого перевезення. Потрібно мати на увазі 
величезну кількість різних складових перевезень, враховувати та раціонально розподіляти ризики між усіма учасниками транспортування. При великих обсягах даних широкого застосування набувають евристичні методи пошуку оптимуму цільової функції. Одними 3 найбільш прогресивних є генетичні алгоритми, які дають змогу знаходити кращі результати за дуже короткий час i 3 мінімальними матеріальними та людськими ресурсами на планування транспортування.

3 метою спрощення транспортних відносин були створені міжнародні комерційні умови, комплект міжнародних правил 3 тлумачення найбільш широко використовуваних торговельних умов Інкотермс (англ. Incoterms). На сьогоднішній день Інкотермс 2020 налічує
11 різних термінів, які широко використовуються в галузі міжнародної торгівлі. Всі поділені на чотири різні групи (E, F, C, D), кожен з них описує конкретний варіант транспортування і умови переходу відповідальності і ризиків від однієї сторони до іншої.

При плануванні перевезення доцільно розподілити його на відповідні етапи транспортування, як це показано на схемі (рис. 1). Це спрощує процес розрахунків i показує, в який саме момент часу обов'язки та ризики переходять до іншої сторони. Особливої уваги потребують ключові відмінності між термінами, акцентовано увагу на проблемних моментах кожного 3 варіантів та виділено переваги і недоліки кожного з них.

\section{INCOTERMS}

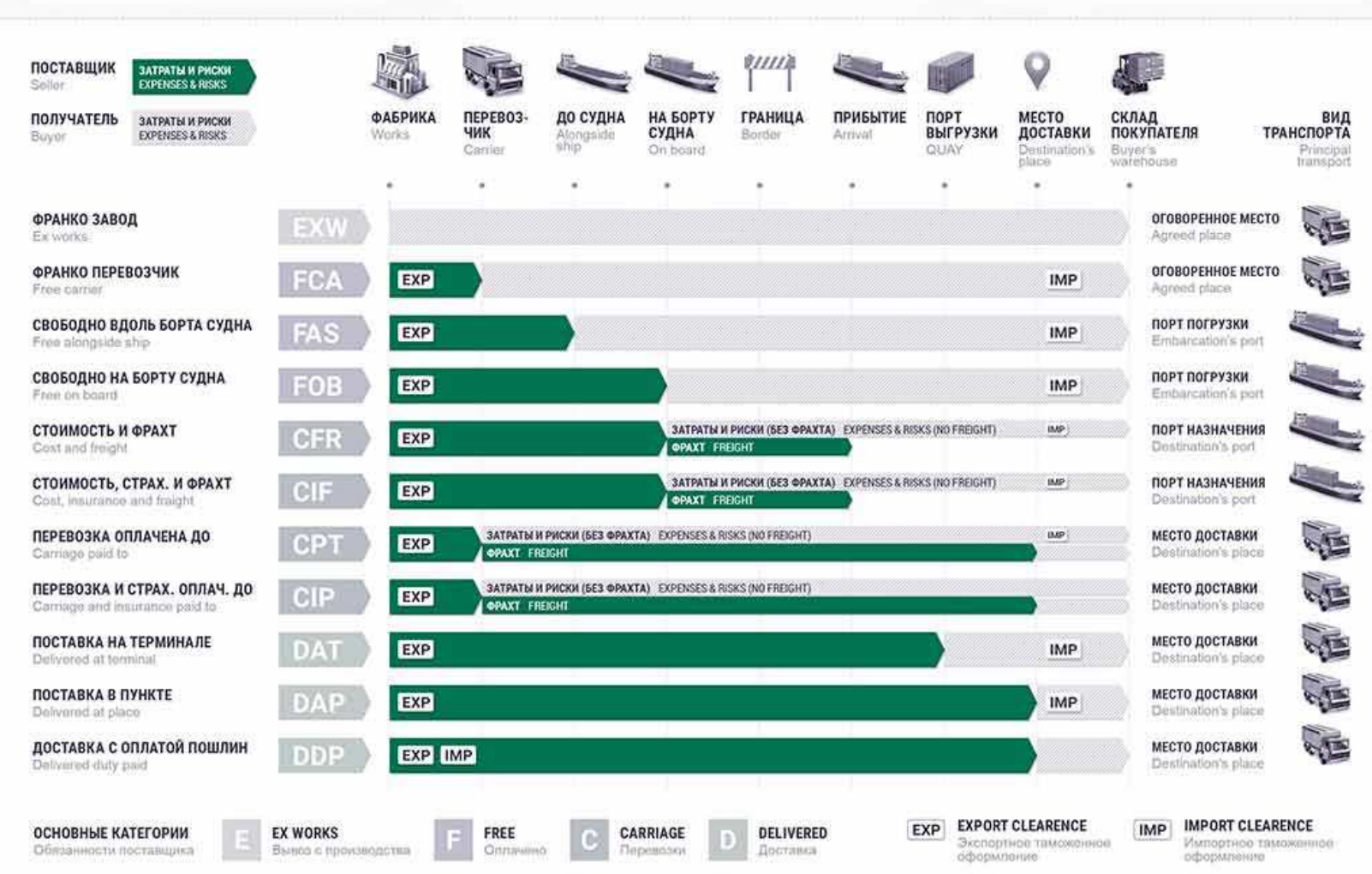

Рис. 1. Порядок здійснення транспортних операцій та розподіл обов'язків між сторонами згідно з правилами Інкотермс 2020 
При міжнародному перевезенні велика увага приділяється митним процедурам та нормативно-правовій базі надання послуги. Оскільки закордонний досвід і технологія транспортування може відрізнятися від українських, будуть різнитися як ціна послуги, так i час на перевезення і всі супутні йому операції. Саме тому автоматизація процесу планування може значною мірою покращити кінцеві результати. Метод генетичних алгоритмів надасть змогу проаналізувати існуючих перевізників та кон'юнктуру ринку і залежно від пріоритетного критерію запропонувати оптимальний для кожної сторони варіант. Також докладний опис показує, що більшість помилок виникає саме через людську неуважність.

Стосовно генетичних алгоритмів - за принципом роботи вони нагадують процес еволюції Дарвіна. «Еволюція», як правило, починається 3 популяції випадково згенерованих особин і $\epsilon$ ітераційним процесом, причому популяція в кожному циклі називається поколінням. У кожному поколінні оцінюється придатність кожної особи у популяції; придатність зазвичай являє собою значення цільової функції в задачі оптимізації, яка вирішується. Також слід наголосити на тому, що деякі параметри алгоритму потрібно задавати користувачу. Конкретно для завдання оптимізації перевезень потрібно враховувати маршрутну швидкість транспортного засобу, якість та завантаженість маршрутів, особливості перевезення, потреби клієнтів, інформацію про вантаж, що надається до транспортування, тощо. Тому вводяться додаткові константні або змінні величини. Маючи ці дані, будується граф 3 відповідними показниками (наочне відображення шляху). Для підвищення швидкості отримання результату шляхи, які заздалегідь не використовуватимуться, доцільно ліквідувати з розрахунків.

У нашому дослідженні існують декілька критеріїв, за якими обиратиметься кінцеве рішення. Отже, буде створюватися декілька масивів даних, по одному для кожного з критеріїв. Транспортна логістика зазвичай вирішує проблеми швидкості доставки вантажу, витрат на перевезення та безпеки транспортування. Для задоволення усіх потреб необхідно запропонувати декілька найкращих варіантів, але кінцеве рішення залишається за людиною. Виконання розрахунків слід відокремити одне від одного для уникнення конкуренції даних між собою.

Цільова функція вартості доставки

$$
3 \mathrm{C}=\mathrm{MB}+\Sigma \mathrm{C}_{\mathrm{i}} \rightarrow \mathrm{min}_{,}
$$

де 3С - загальна вартість перевезення; $\mathrm{Ci}$ собівартість перевезення і-го виду транспорту; МВ - митна вартість.

Як було зазначено вище, митні витрати відіграють критичну роль при виборі базисних умов. Існує декілька різних способів розрахунку митних витрат. Для нашої роботи ми скористалися способом на основі додавання вартості. Оцінка митної вартості здійснюється шляхом складання різних видів витрат і прибутку експортера.

Митна вартість на основі додавання

$\mathrm{MB}=\mathrm{BB}+\mathrm{BH}+\mathrm{H \Pi}+\mathrm{B \Pi}+\pi \Pi+4 \Pi,(2)$

де ВВ - вартість матеріалів і витрат, яких зазнав виробник у зв'язку з виробництвом оцінюваних товарів; ВД - витрати в Україні на вантаження, розвантаження, транспортування і страхування; НП прибуток, що отримує експортер; ВП витрати покупця; ЛП - ліцензійні та інші платежі за використання об'єктів інтелектуальної власності, які покупець повинен здійснити як умову експорту товару, що оцінюється; ЧП - відповідна 
частина прибутку від подальшого перепродажу товарів, що накопичуються у продавця.

Цільова функція часу доставки

$$
\mathrm{T}_{\text {даст }}=\mathrm{T}_{\mathrm{p}}+\mathrm{T}_{\mathrm{n}-\mathrm{K}}+\mathrm{T}_{\mathrm{n}}+\mathrm{T}_{6} \rightarrow \min \text {, }
$$

де $\mathrm{T}_{\mathrm{p}}$ - час руху; $\mathrm{T}_{\text {п-к }}-$ час на початковокінцеві операції; $\mathrm{T}_{п}-$ час на простої; $\mathrm{T}_{б}-$ буферний час.
Вираз $\mathrm{f}(\mathrm{Hj}) \rightarrow \min , \mathrm{j}=1,2,3 \ldots \mathrm{N}$ показує, що проводиться операція мінімізації даних. Обираються лише ті індивіди, які містять у собі менші значення. 3 точки зору математики вони мають такий вигляд:

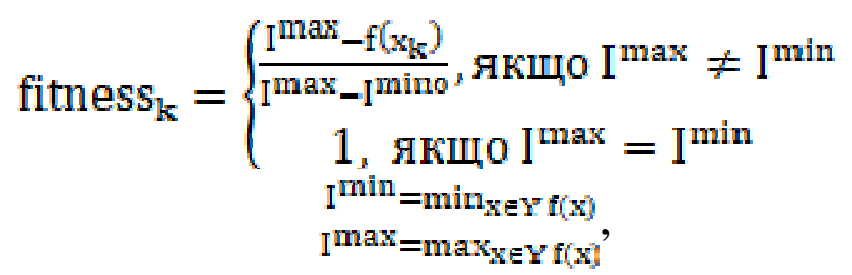

де I - безліч представлених індивідами значень цільової функції в поточному поколінні; х - фенотип; $\mathrm{f}(\mathrm{Xk})$ - значення цільової функції; $\mathrm{k}$ - номер фенотипу.
Порядок виконання операцій у генетичному алгоритмі подано на схемі (рис. 2):

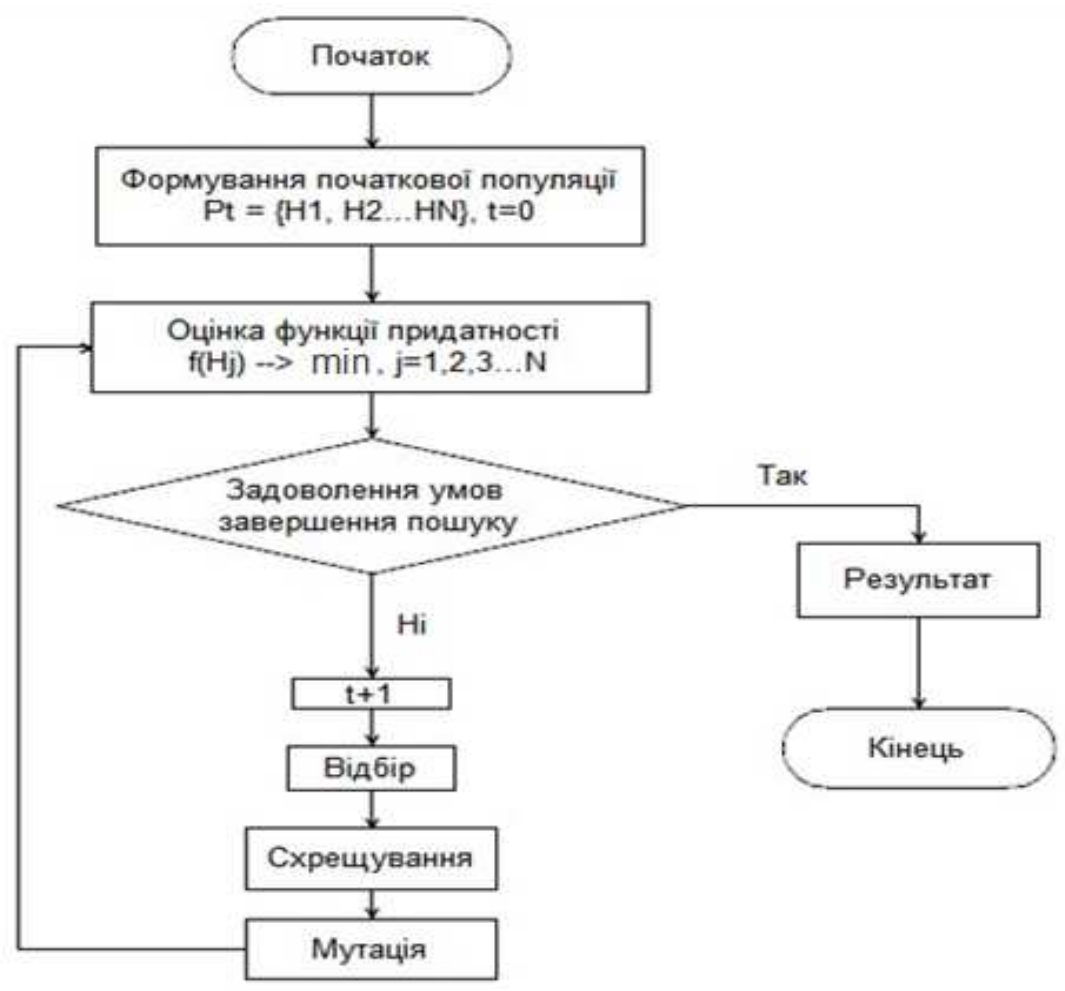

Рис. 2. Процедура виконання генетичного алгоритму 
Кожна стохастична модель повинна мати обмеження цільової функції. У нашому випадку такими обмеженнями слугуватимуть дані, які вводяться людиною. Оскільки немає певної сталої величини, яка б обмежувала вартість і час на перевезення, потрібно заносити ці величини до алгоритму кожного разу. Так, наприклад, перша сторона встановлює максимальний час на перевезення, який алгоритм не має права перевищувати. Таким чином ми виключаємо більшість варіантів, які заздалегідь не відповідають умовам перевезення та вимогам клієнтів. Те саме стосується і вартості доставки. Учасники перевезення мають становити певний грошовий максимум, за межами якого пошук оптимального рішення не проводиться.

Висновки. Ринкова економіка та зростання обсягів міжнародної торгівлі спонукають перевізників до покращення i раціоналізації планування перевезення. Комп'ютеризація цього процесу надасть можливість:

1) значно скоротити час на пошук оптимальних рішень виходячи 3 критеріїв часу та вартості;

2) зменшити ризики та вірогідність виникнення помилок;

3) враховувати нормативно-правову базу країн імпортерів/експортерів.

Створення автоматизованих систем позитивно впливатиме на транспортнологістичну галузь у нашій країні. Україна матиме чудовий шанс на покращення перевізних послуг і створить сприятливі умови для підвищення іміджу країни в очах закордонних клієнтів. Запропонована інновація не потребує значних капіталовкладень i може створити позитивний економічний ефект за рахунок зменшення собівартості від впровадження технології.

\section{Список використаних джерел}

1. Incoterms 2020 - значение термина. URL: https://www.alta.ru/information/glossarium/ инкотермс_2020_incoterms_2020/ (дата звернення: 03.10.2020).

2. Инкотермс 2020, изменения в условиях поставок. URL: https://anvay.ru/incoterms-2020 (дата звернення: 03.10.2020).

3. Інкотермс. Матеріал з Вікіпедії - вільної енциклопедії. URL: https://ru.wikipedia.org/ wiki/Інкотермс (дата звернення: 03.10.2020).

4. ICC INTERNATIONAL CHAMBER OF COMMERCE. URL: https://iccwbo.org/resources -for-business/incoterms-rules/incoterms-2020/ (дата звернення: 03.10.2020).

5. Баланов В. О. Огляд раціональних шляхів розвитку залізничних перевезень міжнародними транспортними коридорами. Транспортні системи та технології перевезень: 3б. наук. праџь Дніпропетровського національного університету залізничного транспорту ім. акад. В. Лазаряна. 2013. Вип. 5. С. 5-11. URL: http://nbuv.gov.ua/UJRN/znpdnu_tstp_ 2013_5_2. (дата звернення: 03.10.2020).

6. Дейнека О.Г., Реброва А. Ю. Визначення чинників впливу на рівень конкурентоздатності залізничного транспорту на міжнародному ринку транзитних перевезень. Проблеми економіки транспорту: зб. наук. праџь Дніпропетровського національного університету залізничного транспорту ім. акад. В. Лазаряна. 2011. Вип. 1. С. 40-43. URL: http://nbuv.gov.ua/UJRN/znpdnuzt_pet_2011_1_8. (дата звернення: 03.10.2020).

7. Intermodal savings calculator. URL: https://www.louplogistics.com/resource-center/ intermodal-savings-calculator.html (дата звернення: 03.10.2020). 
8. Угода між Кабінетом Міністрів України та Урядом Турецької Республіки про міжнародні комбіновані перевезення від 04.10.2017. URL: https://zakon.rada.gov.ua/laws/ show/792_001-16\#Text (дата звернення: 03.10.2020).

9. Вовк В. М., Нєфьодова Ю. М. Особливості формування собівартості вантажних перевезень транспортом перевізників за базисних умов поставок Інкотермс. Вісник Начіонального університету водного господарства та природокористування. Економічні науки. 2016. Вип. 1. С. 28-35. URL: http://nbuv.gov.ua/UJRN/Vnuvgp_ekon_2016_1_6. (дата звернення: 03.10.2020).

10. Сорокіна С. В., Маслов А. А., Шкурко С. Л. Особливості застосування правил Інкотермс 2010 у митній справі. Прогресивні техніка та технологї харчових виробництв ресторанного господарства і торгівлі. 2012. Вип. 1. С. 539-547.

URL: http://nbuv.gov.ua/UJRN/Pt_2012_1_86. (дата звернення: 03.10.2020).

11. Грущинська Н. М., Антоненко К. В. Інкотермс як головний документ регулювання базисних умов поставки при управлінні експортно-імпортними операціями підприємства України з урахуванням європейських стандартів. Вісник Академії митної служби України. Серія: Економіка. 2009. № 1. С. 93-100. URL: http://nbuv.gov.ua/UJRN/vamsue_2009_1_16. (дата звернення: 03.10.2020).

12. Бутько Т. В. Прохоров В. М., Чехунов Д. М. Технологія інтелектуального управління сортувальною станцією на основі багатоцільової оптимізації з використанням генетичних алгоритмів. Інформаційно-керуючі системи на залізничному транспорті. 2018. № 4. C. 45-55. URL: http://lib.kart.edu.ua/handle/123456789/4484 (дата звернення: 03.10.2020).

13. Себестоимость перевозки груза. URL: https://studfile.net/preview/5877367/page:29/ (дата звернення: 03.10.2020).

14. Методи визначення митної вартості товару. URL: https://uk.wikipedia.org/wiki/ Методи_визначення_митної_вартості_товару (дата звернення: 18.12.2020).

15. Расчет времени и скорости доставки грузов. URL: http://www.transpobrand.ru/tabras823-1.html (дата звернення: 03.10.2020).

16. Генетичний алгоритм. URL: https://uk.wikipedia.org/wiki/Генетичний_алгоритм (дата звернення: 03.10.2020).

17. Журавлев С. Ю., Фейгин В. С. Генетический алгоритм решения многокритериальной задачи оптимизации энергозатрат при использовании машиннотракторных агрегатов. Вестник Красноярского государтвенного аграрного университета. 2013. C. 182-191. URL: https://cyberleninka.ru/article/n/geneticheskiy-algoritm-resheniyamnogokriterialnoy-zadachi-optimizatsii-energozatrat-pri-ispolzovanii-mashinno-traktornyhagregatov/viewer (дата звернення: 03.10.2020).

18. Кондратьева А. В. Построение оптимального маршрута и его визуализация с помощью WebGL. Руководитель дипл. работы A. В. Уланов. Санкт-Петербургский нац. ун-т. 2016. URL: https://dspase.spbu.ru.

\footnotetext{
Ломотько Денис Вікторович, доктор технічних наук, професор, завідувач кафедри транспортних систем та логістики Українського державного університету залізничного транспорту. ORCID iD: 0000-0002-7624-2925. Тел.: +38 (057) 730-19-55. E-mail: den@kart.edu.ua.

Ковальов Денис Дмитрович, магістрант, група 11-ІІм-ОПУТ-мд Українського державного університету залізничного транспорту. Тел.: +38 (098) 408-83-03. E-mail: dkovalov123@ gmail.com.
}

Lomotko Denis, Dr. Sc. (Tech.), professor, head of department of Transport Systems and Logistics at Ukrainian State University of Railway Transport. ORCID iD: 0000-0002-7624-2925. Tel.: +38 (057) 730-19-55.

E-mail: den@kart.edu.ua.

Kovalov Denis, master, Group 11-IIm-OPUT-md, Ukrainian State University of Railway Transport. 
Збірник наукових праць Українського державного університету залізничного транспорту

Tel.: +38 (098) 408-83-03. E-mail: dkovalov123@gmail.com.

Статтю прийнято 06.11.2020 p. 